Original Article

\title{
Seasonal plankton succession is in accordance with phycotoxin occurrence in Disko Bay, West Greenland
}

\author{
Claudia Sabine Bruhn ${ }^{\mathrm{a}, *}$, Sylke Wohlrab ${ }^{\mathrm{a}, \mathrm{b}}$, Bernd Krock ${ }^{\mathrm{a}}$, Nina Lundholm ${ }^{\mathrm{c}}$, Uwe John ${ }^{\mathrm{a}, \mathrm{b}}$ \\ ${ }^{a}$ Alfred Wegener Institute, Helmholtz Centre for Polar and Marine Research, Am Handelshafen 12, 27570 Bremerhaven, Germany \\ ${ }^{\mathrm{b}}$ Helmholtz Institute for Functional Marine Biodiversity, Ammerländer Heersstraße 231, 26129 Oldenburg, Germany

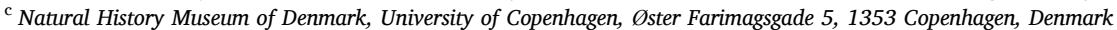

\section{A R T I C L E I N F O}

\section{Keywords:}

Arctic

Phytoplankton

Protist

Time series

Harmful algal bloom

\begin{abstract}
A B S T R A C T
Harmful algal blooms (HABs) are occurring more frequently in the world's oceans, probably as a consequence of climate change. HABs have not been considered a serious concern in the Arctic, even though the Arctic warms faster than any other region. While phycotoxins and toxin-producing phytoplankton have been found in Arctic waters on several occasions, there is a lack of information on seasonal succession of species and whether the occurrence of harmful species correlates with the presence of their respective phycotoxins. Hence, there is no baseline to assess future changes of HABs in this area. Here, we investigated two periods, from winter to spring and from the spring bloom until summer, in Disko Bay, West Greenland and followed the succession of toxins and their producers using metabarcoding, as well as analyses of particulate and dissolved toxins. We observed a typical seasonal succession with a spring bloom dominated by diatoms, followed by dinoflagellates in summer, with the two most important potentially toxic taxa found being Pseudo-nitzschia spp. and Alexandrium ostenfeldii. The Pseudo-nitzschia spp. peak correlated with a clear increase in particulate domoic acid, reaching $0.05 \mathrm{pg} / \mathrm{L}$. Presence of Alexandrium ostenfeldii could be linked to an increase in spirolides, up to $56.4 \mathrm{pg} / \mathrm{L}$ in the particulate phase. Generally, the majority of detected dissolved toxins followed the succession pattern of the particulate toxins with a delay in time. Our results further show that Arctic waters are a suitable habitat for various toxin producers and that the strong seasonality of this environment is reflected by changing abundances of different toxins that pose a potential threat to the ecosystem and its beneficiaries.
\end{abstract}

\section{Introduction}

Phytoplankton responses to ongoing and future environmental change will significantly affect earth system processes at many scales. These primary producers are the photosynthetic base of marine food webs and responsible for approximately half of the global oxygen production (Falkowski, 1994; Field et al., 1998). In the Arctic, climate change is progressing at a much faster rate than the global average (Overpeck et al., 1997; McBean et al., 2005; IPCC, 2007), hence the Arctic is one of the quickest changing ecosystems in the world, warming at a significantly higher rate than other regions (Moritz et al., 2002; Mauritsen, 2016). An increased risk of future HAB events in the Arctic is therefore anticipated, as potential $\mathrm{HAB}$ species from temperate regions may migrate further north and establish themselves in the Arctic ecosystems.

Greenland is dependent on a healthy marine ecosystem. The fishing industry provides Greenland's most important marketable goods for export (Brett, 2003; Vahl and Kleemann, 2019) and many private households are dependent on marine resources, like hunting marine mammals, for regular sustenance (Vahl and Kleemann, 2019). The marine ecosystem, which is the fundament of these resources, heavily relies on a direct link from diatoms via copepods to marine mammals in spring, when considering latitudes as high as most of Greenland. In the Arctic, a more pronounced microbial loop, as it is typical for temperate regions, is usually observed in summer. At this time, microbial biomass is generally relatively low, making the direct short food web link, which is dominant in spring, much more relevant to food production for the native population (Hobson and Welch, 1992; Seuthe et al., 2011). This increases the possible impact of a change in the microbial spring diversity on the Greenlandic population. Besides the beneficial impact of microbial eukaryotes, some of them can form harmful algal blooms (HABs), which can have adverse effects on the marine ecosystem

\footnotetext{
* Corresponding author.

E-mail addresses: claudia.bruhn@awi.de (C.S. Bruhn), uwe.john@awi.de (U. John).
} 
function and services. Only a few studies have described succession dynamics of primary producers and $\mathrm{HAB}$ species in particular in the Arctic (Marquardt et al., 2016), although it is crucial to know the status quo for identifying future risks and recognizing changes of the plankton community structure and therefore changes in the entire ecosystem.

General consensus exists about a global increase in HABs (Van Dolah, 2000; Hallegraeff, 2003; Anderson et al., 2012), and many of the factors promoting HABs are linked to the effects of climate change (Hallegraef, 2010; Wells et al., 2015). Increased water temperature and water column stratification are a direct result of increased atmospheric $\mathrm{CO}_{2}$ levels and therefore global warming (IPCC, 2014; McCarthy et al., 2015), and both factors are broadly recognized as a risk factor for HABs (Peperzak, 2003; Ralston et al., 2014; Wells et al., 2015). Possible effects of melting glaciers, a known result of climate change, are changing water salinity and nutrient upwelling events from lower ocean layers by promoting subsurface meltwater plumes (Meire et al., 2017). Additionally, melting land-terminating glaciers may wash out nutrients from freshly thawed permafrost, carrying terrestrial nutrients into the ocean (McCarthy et al., 2015; Wadham et al., 2016; Meire et al., 2017), and therefore potentially increasing the risk for future $\mathrm{HABs}$ even further.

Some HAB species and toxins have already been detected in the Arctic. Presence of domoic acid (DA)-producing Pseudo-nitzschia species has been shown off West Greenland, Iceland, and in Barrow Strait, Beaufort Sea, Baffin Bay as well as subarctic parts of Norway (Hasle, 2002; Hansen et al., 2011; Harðardóttir et al., 2015; Lundholm et al., 2018). The toxin itself was detected in phytoplankton in West Greenland, reaching as far as $71^{\circ} \mathrm{N}$ (Elferink et al., 2017). In 2017, Pseudo-nitzschia spp. occurrences caused elevated DA contents in Mytilus edulis, resulting in a local harvesting ban close to Dønna, Norway at 665'N (HAEDAT, 2017).

The vast majority of toxigenic species are dinoflagellates (Smayda, 1997), and their toxins have also been detected in Arctic waters. Paralytic shellfish poisoning (PSP) toxins exceeded the limit of $800 \mu \mathrm{g} / \mathrm{kg}$ shellfish in 2003 in the Attu region $\left(67^{\circ} 50^{\prime} \mathrm{N}-68^{\circ} 10^{\prime} \mathrm{N}, 53^{\circ} 00^{\prime}\right.$ W-54 $00^{\prime}$ ' W) at the west coast of Greenland (Baggesen et al., 2012). In August 2005, saxitoxin-producing Alexandrium catenella (formerly reported as A. tamarense, now renamed as A. catenella; John et al., 2014), was found in the same area and considered as the causative agent of the PSP event (Baggesen et al., 2012). Pectenotoxin-1 was found at levels of $467 \mu \mathrm{g} / \mathrm{kg}$ shellfish in the Chuckchi Sea at approximately $74{ }^{\circ} \mathrm{N}$, well exceeding the safety regulation for consumption (Gao et al., 2019). Spirolides are potentially toxic hazards, which have not yet been confirmed to be a threat to humans in situ (Richard et al., 2000; Munday et al., 2012). Spirolides have by now not been shown to be produced by other species than A. ostenfeldii (Cembella et al., 2000, 2001). Some A. ostenfeldii strains are capable of producing other, probably more harmful toxins, such as paralytic shellfish poisoning (PSP) toxins and gymnodimines (GYM) (Munday et al., 2012; Martens et al., 2017). In Uummannaq Fjord in West Greenland (around $71^{\circ} \mathrm{N}$ ), A. ostenfeldii was found in 2012 (Tillmann et al., 2014). Alexandrium ostenfeldii was also observed in the Russian Arctic, albeit without evidence of toxin-producing activity (Okolodkov et al., 1996). Azaspiracid-producing Amphidoma languida was found in the Subarctic Irminger Sea (Tillmann et al., 2015), and Azadinium spp. and Amphidoma spp. have been observed along the coast of Norway (Tillmann et al., 2018).

HABs can severely affect higher trophic levels, including humans and animals (Bates et al., 2018) and consequently result in negative health and economic consequences. Higher trophic levels such as marine mammals have been reported to bioaccumulate toxins in the Arctic, and HABs thus represent a rarely studied and hidden risk (Lefebvre et al., 2016). As many known HAB species have been detected in the Arctic and Subarctic, a potential for HAB development exists, although the record of actual Arctic HAB events seems to be relatively low. Part of this may be due to a study bias, because the Arctic is less accessible for routine field studies. This is reflected by reports of snapshot or transect studies, mainly from research cruises, which do not account for the yearly development in the highly seasonal environment as done by monitoring programs. However, only long-term datasets can reveal overall changes in the community, dynamics and resulting threats that may be caused by HABs (Hinder et al., 2012). Our study therefore provides a characterization of the natural succession and presence of HAB species during two field periods of approximately three months length each. We will particularly focus on the dynamics of different potential $\mathrm{HAB}$ species and their succession patterns around the spring bloom season to evaluate the risk for $\mathrm{HAB}$ events in the future.

\section{Material and methods}

\subsection{Site description and Sampling procedure}

The sampling stations were located close to the Arctic Station in Qeqertarsuaq, Disko Island, West Greenland. Water samples were taken with a 25 L Niskin Water sampler (KC Denmark) in an area of approximately $6 \mathrm{~km} \times 2 \mathrm{~km}\left(69^{\circ} 11^{\prime} 00^{\prime \prime} \mathrm{N}\right.$ to $69^{\circ} 15^{\prime} 14^{\prime \prime} \mathrm{N}$ and $53^{\circ} 25^{\prime} 36^{\prime \prime} \mathrm{W}$ to $53^{\circ} 31^{\prime} 15^{\prime \prime} \mathrm{W}$ ), depending on the conditions of sea ice or the presence of icebergs (Fig. 1). The area was sampled in the time periods May 1, 2017 to July 27, 2017, and February 10, 2018 to April 23, 2018 as close to noon as possible. Sampling was performed every second week at three distinct stations, except for winter when only one station was sampled but at a higher frequency of approximately every four days. Sampling of dissolved toxins was performed with SPATT (Solid Phase Adsorption Toxin Tracking) samplers at another, more enclosed location $\left(69^{\circ} 16^{\prime} 00^{\prime \prime}\right.$ N, $53^{\circ} 46^{\prime} 24^{\prime \prime}$ W) (Fig. 1). The sampling location for the SPATT samplers was selected as a compromise for being safe from icebergs, good accessibility throughout the year, and qualitative proximity to the original sampling stations.

Sampling containers were pre-treated with $3 \%$ hydrochloric acid and rinsed with fresh water thoroughly between samplings. The containers were flushed twice with the respective sample before collecting $10 \mathrm{~L}$ of seawater from $5,10,20,30$ and $40 \mathrm{~m}$ depth. Salinity and temperature were measured manually from the sampled waters until May 14. From May 2017 on, a SonTek CastAway-CTD or a Seabird SBE 911plus CTD were used for additional oceanographic data. Comparability of the values was ensured by measuring in parallel with the different devices. To restrict degradation of the samples, they were stored cool and dark before being processed within $24 \mathrm{~h}$ after sampling.

\subsection{Sample preparation and analysis}

Water samples from different depths at the same sampling station were pooled before the following treatments were performed:

Samples for inorganic nutrient measurements (ammonium, nitrate, nitrite, phosphate and silicate) were transferred from the pooled sample to polypropylene bottles $(50 \mathrm{~mL})$ and frozen immediately at $-20{ }^{\circ} \mathrm{C}$. Nutrient samples were analyzed with a continuous-flow autoanalyzer (Evolution III, Alliance Instruments, France) based upon standard seawater analytical methods for determination of nitrate and nitrite (Armstrong et al., 1967), ammonium (Koroleff, 1969), silicate (Grasshoff et al., 1983), and phosphate (Eberlein and Kattner, 1987).

For chlorophyll $a$ analyses, $1 \mathrm{~L}$ of pooled sample was filtered through glass microfiber filters (Whatman GF/F, Whatman, UK; nominal pore size: $0.7 \mu \mathrm{m}$ ), packed in aluminum foil and frozen at $-20{ }^{\circ} \mathrm{C}$ until analysis, maximum four weeks after sampling. Chlorophyll $a$ was extracted from the filters by incubation in $10 \mathrm{~mL}$ of methanol (modified after EPA method 445.0-1, Arar and Collins, 1997) at $-20^{\circ} \mathrm{C}$ overnight. The extract was measured at $665 \mathrm{~nm}$ (TD-700 fluorometer, Turner Designs, USA, calibrated with Anacystis nidulans chlorophyll, Sigma-Aldrich).

For POC and PON analysis, $1 \mathrm{~L}$ of pooled sample was filtered through pre-combusted glass microfiber filters (Whatman GF/F, Whatman, UK; nominal pore size: $0.7 \mu \mathrm{m}$ ) and frozen in pre-combusted glass vials before analysis. For analysis, the wet filters were dried at $50{ }^{\circ} \mathrm{C}$ 


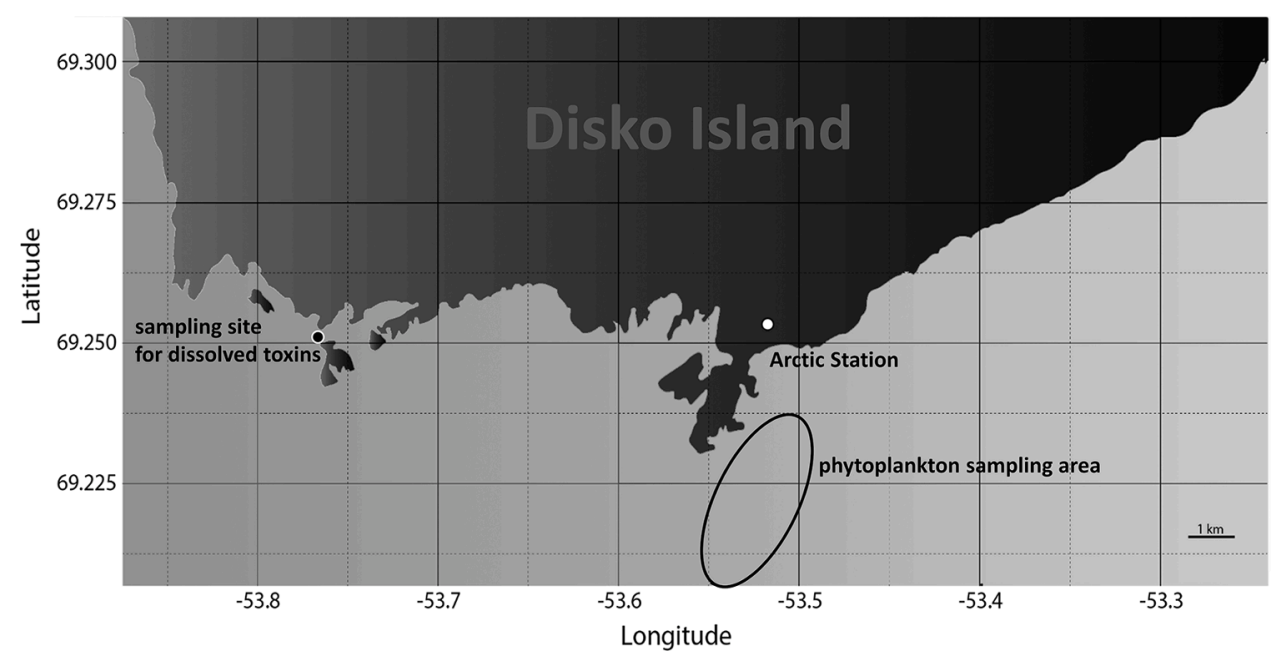

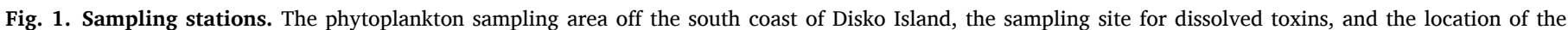
research base Arctic Station.

overnight. Half of the dried filter was acidified with $300 \mu \mathrm{L} 0.2 \mathrm{~N} \mathrm{HCl}$ and again dried overnight at $50{ }^{\circ} \mathrm{C}$, the other half was frozen as a backup. The acidified and dried filters were packed in tin foil and analyzed on a Euro Elemental Analyzer 3000 CHNS-O (HEKAtech $\mathrm{GmbH}$, Germany). POC:PON ratios from February 10 through 21 were excluded because of very low cell biomass.

\subsection{Metabarcoding}

The remaining pooled water sample was filtrated through a series of filters for size fractionation. A $200 \mu \mathrm{m}$ nylon mesh was used to decrease the amount of debris and larger zooplankton. As the size fraction above $200 \mu \mathrm{m}$ was discarded, some larger phytoplankton cells and colonies were removed as a consequence. The filtrate was subsequently size fractionated in three filtration steps with a $20 \mu \mathrm{m}$ nylon mesh (filtering $47.5 \mathrm{~L}$ ), and polycarbonate filters with pore sizes of $3 \mu \mathrm{m}$ (filtering $3 \mathrm{~L}$ ) and $0.2 \mu \mathrm{m}$ (filtering $1 \mathrm{~L}$ ) using a vacuum pump at minimum $-500 \mathrm{mbar}$. The size fractions will hereafter be referred to as picoplankton $(0.2 \mu \mathrm{m}$ to $3 \mu \mathrm{m}$ ), nanoplankton ( $3 \mu \mathrm{m}$ to $20 \mu \mathrm{m}$ ) and microplankton ( $20 \mu \mathrm{m}$ to 200 $\mu \mathrm{m})$. DNA was extracted with a NucleoSpin Soil kit (Macherey-Nagel, Germany). Metabarcoding libraries were prepared according to $16 \mathrm{~S}$ Metagenomic Sequencing Library Preparation protocol by Illumina, with the primers being adapted for the eukaryotic V4-region (Piredda et al., 2016). After sequencing with the Illumina MiSeq system, the clustering and annotation of OTUs (Operational Taxonomic Units) was performed utilizing a pipeline developed in house (as described by Sprong et al., 2020) with the reference database $\mathrm{PR}^{2}$ (version 4.11.1, Guillou et al., 2013). To gain further insight and a better-curated system, the taxonomic groups of dinoflagellates, diatoms and haptophytes were additionally annotated on taxonomic trees (Elferink et al., 2017) and subsequently manually curated. Further, the data was normalized, fungi and metazoan sequences were removed, as well as singletons and doubletons as potential artifacts. This and further data preparation was done in R, version 3.6 with RStudio, version 1.3.959 and the packages effects, ggplot2, plyr, phyloseq, and vegan.

\subsection{Toxin analysis}

Two distinct approaches were used to monitor the toxins presented in Table 2. For particulate toxin content, plankton net (pore size $20 \mu \mathrm{m}$, $40 \mathrm{~cm}$ diameter; Hydro-Bios, Kiel, Germany) samples were hauled from $40 \mathrm{~m}$ depth at the same locations and time points as the water samples. We estimate that a maximum of approximately $5000 \mathrm{~L}$ water was filtered with each net tow, depending on the density of particles in the water (Brander et al., 1993). The dense plankton net sample was diluted with surface water and stored cold a few hours until processing to minimize cell death and lysis. Most zooplankton (and some larger phytoplankton cells and colonies) was removed by a $200 \mu \mathrm{m}$ mesh filtration, the samples were collected on a $20 \mu \mathrm{m}$ mesh, split in four even aliquots with a pipette and pelleted by centrifugation. Pellets were frozen at $-20{ }^{\circ} \mathrm{C}$ until toxin extraction. Two aliquots were spiked with $0.9 \mathrm{~g}$ of lysing matrix D (Thermo Savant, Illkirch, France) and with methanol and $0.03 \mathrm{M}$ acetic acid, respectively. The cells were lysed and extracted in a FastPrep homogenizer (Thermo Savant) by reciprocal shaking at $6.5 \mathrm{~m} / \mathrm{s}$, and subsequently centrifuged at $16,100 \times \mathrm{g}$ for 15 min. After filtering the supernatant through Ultrafree MC Filter units (Millipore), one aliquot was analyzed for hydrophilic paralytic shellfish poisoning (PSP) toxins by ion-pair chromatography coupled to post-column derivatization and fluorescence detection as detailed in Van de Waal et al. (2015). The other aliquot was analyzed for lipophilic phycotoxins by reversed phase liquid chromatography coupled to tandem mass spectrometry (LC-MS/MS) as detailed in Krock et al. (2008) with additional mass transitions for goniodomin $\mathrm{A}$ and desmethyl-goniodomin A $(m / z 786.5 \rightarrow 733.5$ and $m / z 772.5 \rightarrow 719.5$, respectively).

Dissolved toxins were sampled by solid phase absorption toxin tracking (SPATT, MacKenzie et al., 2004). SPATT samplers with Diaion HP20 (Sigma, Deisenhofen, Germany) were prepared as described in Krock et al. (2020) before deployment. The samplers were not placed in the sampling area for particulate plankton, because this location was too open and iceberg occurrences would have interfered with the samplers. Instead, SPATT samplers were deployed in a small bay in the vicinity $\left(69^{\circ} 15^{\prime} 060^{\prime} \mathrm{N}, 53^{\circ} 46^{\prime} 024^{\prime \prime} \mathrm{W}\right)$, at a depth of $8.5 \mathrm{~m}$ below surface. SPATT sampler monitoring was performed between May 1, 2017 and April 30, 2018, where they were exchanged approximately once per month with a time span ranging from $18 \mathrm{~d}$ in the times with higher primary production up to $43 \mathrm{~d}$ during less productive phases. From September 19, 2017 to October 18, 2017 it was not possible to deploy new samplers. After retrieval, the samplers were air dried at room temperature and subsequently frozen at $-20{ }^{\circ} \mathrm{C}$ until analysis. SPATT sampler were desalted by rinsing three times with deionized water and subsequently dried over night at $50^{\circ} \mathrm{C}$. The dry resin was transferred to $50 \mathrm{~mL}$ centrifugation tubes and stored at $-20{ }^{\circ} \mathrm{C}$ until extraction. For extraction, $30 \mathrm{~mL}$ methanol were added to the resin and gently shaken overnight. Subsequently, the methanolic resin suspension was poured into a glass chromatography column and methanol was eluted dropwise until reaching the surface of the resin layer. Subsequently, the centrifugation tube was rinsed with $25 \mathrm{~mL}$ methanol and the methanol was 
added to the resin column. Finally, the resin was extracted with additional $100 \mathrm{~mL}$ methanol. The combined eluates were collected in a glass flask and concentrated to approximately $1 \mathrm{~mL}$ in a rotary evaporator. The extract was spin filtered $(0.45 \mu \mathrm{m}$ pore size $)$ and the filtrate transferred into an HPLC vial, taken to dryness under a gentle nitrogen stream and finally reconstituted in $200 \mu \mathrm{L}$ methanol. SPATT samples were analyzed for lipophilic phycotoxins as described above.

\section{Results}

\subsection{Seasonal biomass, nutrients and temperature}

The biomass markers POC, PON and chlorophyll $a$ all peaked at the sampling in the end of March 2017. All three values behaved largely the same in their tendencies of increasing and decreasing with slight variations in the strength of in- and decrease (Fig. 4C). Chlorophyll $a$ levels peaked at $3.41 \mu \mathrm{g} / \mathrm{L}, \mathrm{POC}$ at $0.65 \mu \mathrm{g} / \mathrm{L}$ and PON at $0.07 \mu \mathrm{g} / \mathrm{L}$. In summer (May-July) 2017, silicate, nitrate and phosphate were decreasing with time (Fig 2A). Ammonium levels varied, but did not show a clear trend. Nitrite levels stayed low, with a slightly higher level in the beginning of this season (Fig. 2A). With progression from spring to summer, water temperature increased continuously and the POC:PONratio decreased (Fig. 2B). Levels of nitrate, silicate and phosphate were overall higher in winter than in summer. Nitrite stayed low at levels comparable to the summer season. Silicate had a slight increasing trend, whereas nitrate and phosphate levels were approximately the same throughout the season. Ammonium levels varied again, overall being a bit lower than in summer (Fig. 2A). The water temperature in winter was uniformly low at approximately $1.5^{\circ} \mathrm{C}$, while the POC:PON followed an upwards trend (Fig. 2B).
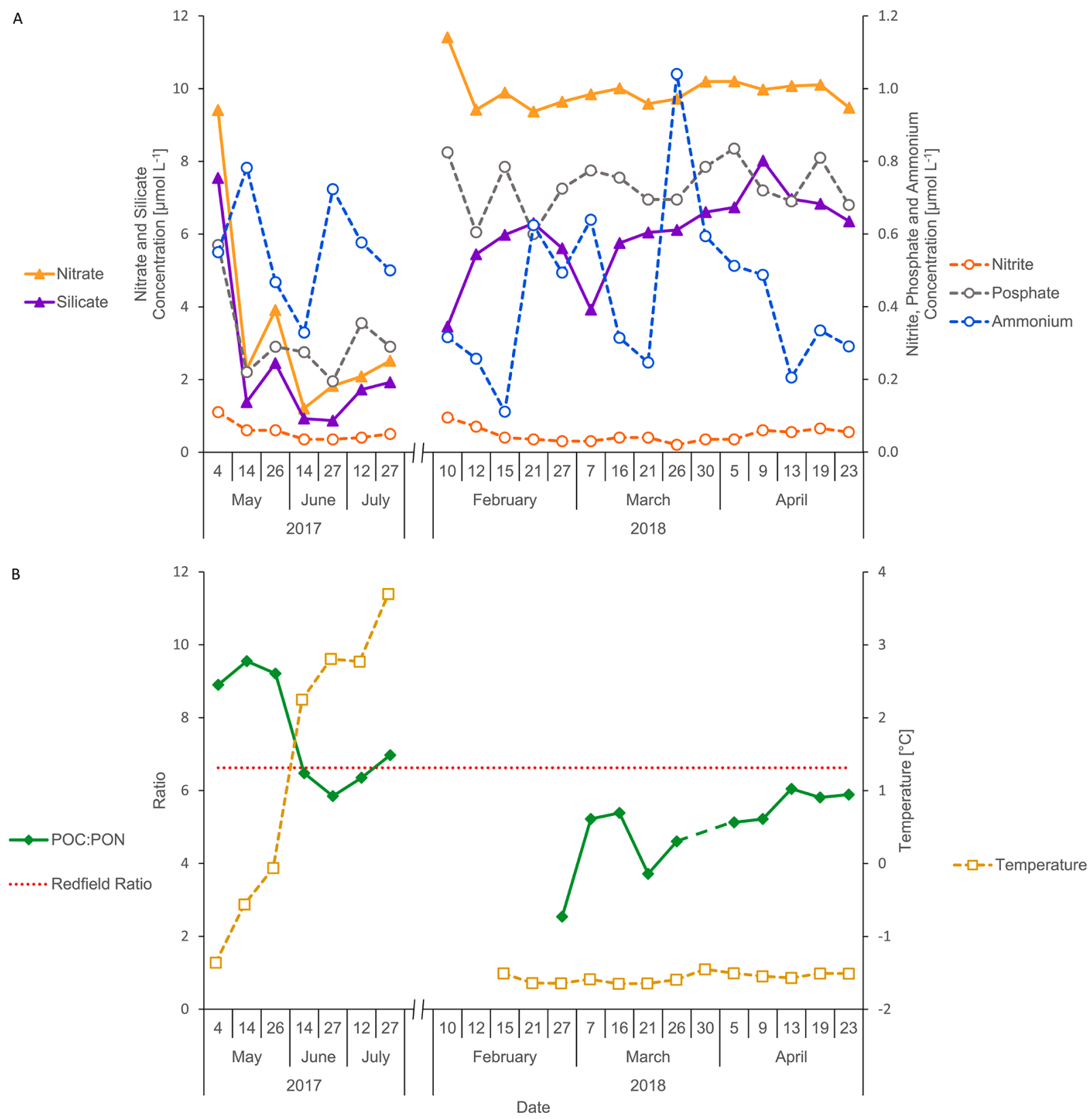

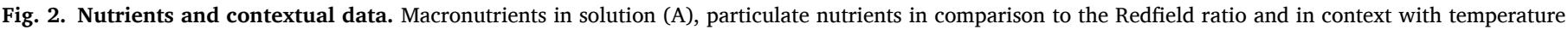

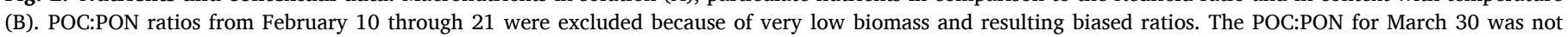

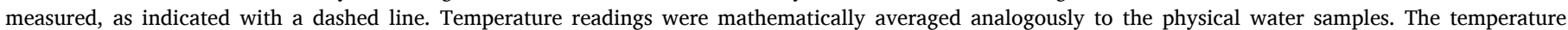
readings of February 10 and 12 were not included due to CTD malfunction. 


\subsection{Potentially toxic species}

Using the IOC-UNESCO taxonomic reference list for defining potentially toxic taxa (Moestrup et al., 2009), eleven potentially toxic taxa of eight genera were detected as OTUs (Table 1). It was possible to identify five toxigenic taxa to species level, namely Alexandrium catenella, Alexandrium ostenfeldii, Dinophysis acuminata, Gonyaulax spinifera, and Protoceratium reticulatum. Because the genera Alexandrium, Dinophysis, Phalacroma (toxicity under debate with hints for toxicity, Reguera et al., 2014), Prorocentrum, Nitzschia and Pseudo-nitzschia contain several toxin-producing species, the reads for these genera were included. The total number of OTU reads from potentially toxic species equalled $1.7 \%$ of all detected OTU reads.

\subsection{Seasonal succession pattern of potential $H A B$ species}

We were able to assign 26,993 different OTUs via $\mathrm{PR}^{2}$ in the combined datasets from 2017 and 2018, of which 1179 could not be assigned to anything more specific than Eukaryota and 37 OTUs were assigned to unclassified Opisthokonta, meaning that it was not possible to completely exclude the possibility of the OTUs to represent a protist species. After excluding fungi, land plants, and animals, 24,698 potential protist-representing OTU reads were left and analyzed for the succession pattern on different phylogenetic levels after normalizing (Fig. 3). HAB relevant dinoflagellates, diatoms and haptophytes were evaluated from the normalized OTU metabarcoding and put into context with the overall protist succession. Potential toxin producers were mainly found in the microplankton size fraction, while they were not present in picoplankton and present to a much lesser extent in the nanoplankton size fraction (Fig. 3B and C). The peak percentage of potentially toxic dinoflagellates was in July 2017 (Fig. 3B), whereas the peak for potentially toxic diatoms was observed in May 2017 (Fig. 3C).

\subsection{Temporal toxin content}

In spring, the phytoplankton biomass peaked on May 26 2017, probably due to a diatom bloom. Most particulate toxins (from cell pellets) reached their highest values more than 47 days later on July 12 and 27 (Fig. 4A, B). The dissolved toxin fraction, which was in contrast measured for almost the entire year, appeared latest three months thereafter in the time period October 18 to November 18. Both in the particulate and dissolved phase, spirolides (SPX) and pectenotoxins (PTX) clustered together, while only dissolved okadaic acid (OA) was associated with these toxins. Dissolved gymnodimine A (GYM A) and azaspiracid-1 (AZA 1) also clustered together. GYM A, OA, dinophysistoxins (DTX), yessotoxins (YTX), and AZA 1 were only detected in the

Table 1.

Statistics of potential HAB species. Singletons, doubletons and tripletons were removed from the pool before assessing the numbers. The per mill value of total detected OTUs values was rounded to three decimal places.

\begin{tabular}{lll}
\hline HAB Taxon & $\begin{array}{l}\text { Number of assigned different } \\
\text { OTUs }\end{array}$ & $\begin{array}{l}\text { Per mill of total amount of } \\
\text { reads }\end{array}$ \\
\hline $\begin{array}{l}\text { Alexandrium catenella } \\
\text { Alexandrium }\end{array}$ & 2 & 0.373 \\
$\quad$ ostenfeldii & 7 & 7.048 \\
Alexandrium spp. & 33 & \\
Dinophysis acuminata & 5 & 0.076 \\
Dinophysis spp. & 17 & 0.511 \\
Gonyaulax spinifera & 2 & 0.02 \\
Phalacroma spp. & 5 & 0.034 \\
Prorocentrum spp. & 22 & 0.654 \\
Protoceratium & 1 & 4.028 \\
$\quad$ reticulatum & & 0.040 \\
Nitzschia spp. & 9 & \\
Pseudo-nitzschia spp. & 4 & 0.396 \\
Total & 107 & 3.989 \\
\hline
\end{tabular}

dissolved phase, whereas DA was the only toxin solely detected in the particulate phase. All other analyzed toxins were either not detected at all or detected in both phases, but at different time points (Table 2). The most abundant toxin group was SPX, which was present and measureable in all sample types. Additionally, DA and PTX were present, although DA could only be detected in the particulate phase. In contrast, GYM only had comparably low amounts detected in the liquid phase (Table 2 and Fig. 4).

\section{Discussion}

\subsection{Seasonality in context of nutrient availability}

The aim of this study was to reveal the natural succession pattern of $\mathrm{HAB}$ species and their phycotoxins in order to assess a potential future risk on the Arctic marine ecosystem. We observed a clear seasonal reciprocal trend of dinoflagellates and diatoms in terms of community dominance (Fig. 2A), with diatoms dominating in spring and dinoflagellates afterwards. This supports previous observations of diatoms dominating the spring bloom biomass, which then quickly consume the nutrients in the mixed layer (Tammilehto et al., 2017), giving way to mixotrophic organisms such as dinoflagellates in the summer period (Raymont, 1980; Smayda and Trainer, 2010; Flynn et al., 2019). This is in accordance with our data, where the nutrients in the spring season were quickly depleted in correlation with high diatom abundance in the microplankton size fraction (Figs. 2 and 3). After the nutrient depletion, the relative dinoflagellate OTU dominance and ammonium levels were increasing (Fig. 2A), as also shown by Glibert (2016).

\subsection{Overall contribution of HAB species OTUs}

In total, eleven potentially toxic dinoflagellate and diatom taxa were found, of which five dinoflagellates were identified to species level. While the overall OTU richness was diverse, the eleven potentially toxic taxa seen in our study contributed to only $1.7 \%$ of total OTU reads (including all size fractions). Hence, we did not observe a HAB, but the respective species were present and an imbalance and further changes in the ecosystem has the potential for HABs to develop in the near future. As expected, the most important size fraction for detected OTUs of HAB species was the microplankton ( $>20 \mu \mathrm{m}$ ) (Fig. 3). Among these, Alexandrium ostenfeldii was the most important dinoflagellate, contributing at times to more than $60 \%$ of all microplankton OTU reads, and peaking together with the overall contribution of dinoflagellates in this size fraction. This larger dinoflagellate contribution of OTUs was taking place after the spring bloom peak at relatively low Chl $a$, POC and PON content. Additionally, the high copy number of ribosomal operons in dinoflagellate genomes often leads to an overestimation of their absolute contribution to the community in metabarcoding approaches because a single cell can contain several copies of the genes relevant for metabarcoding (Guo et al., 2016). This may indicate a rather low absolute abundance of $A$. ostenfeldii at the cellular level and a method-based overestimation of dinoflagellates in general. Still, the contribution to the overall OTUs of $A$. ostenfeldii was notable, and most prominent in July. The most abundant toxic diatom taxon based on the OTU data was the genus Pseudo-nitzschia, which contributed about $14 \%$ of all microplankton OTU reads at the time of the spring bloom peak. The danger of $\mathrm{HAB}$ events partly lies in their spatiotemporal unpredictability, as they are often influenced by wind-induced upwelling or other non-seasonal events (Zingone and Oksfeldt Enevoldsen, 2000; Pitcher and Weeks, 2006). A strongly seasonal environment such as the Arctic may be different, as the potentially toxic organisms strongly correlate with the overall seasonal bloom pattern in the present study. On the other hand, it is known that the exact composition of the Arctic spring bloom varies considerably from year to year (Hegseth and Tverberg, 2013; Fragoso et al., 2017), which may imply similar risks in this region. 


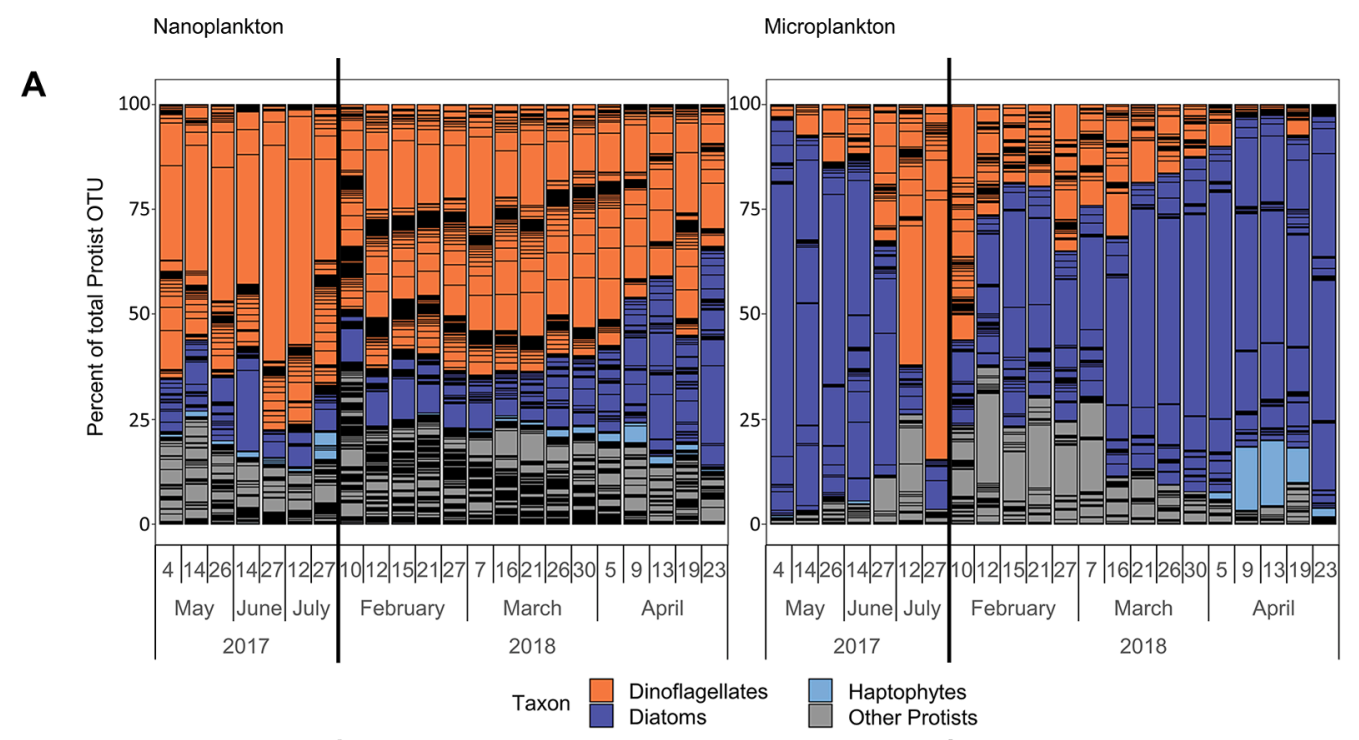

B
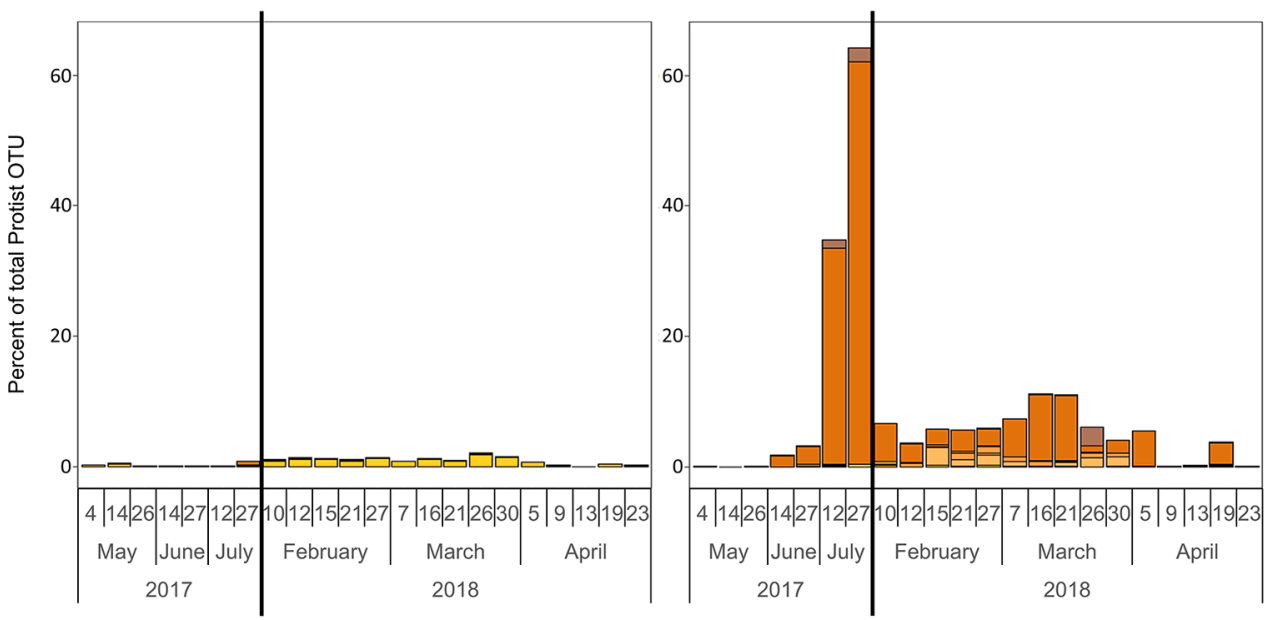

Toxigenic Dinoflagellate Species

Alexandrium catenella Alexandrium ostenfeldi

Alexandrium spp. Prorocentrum spp.

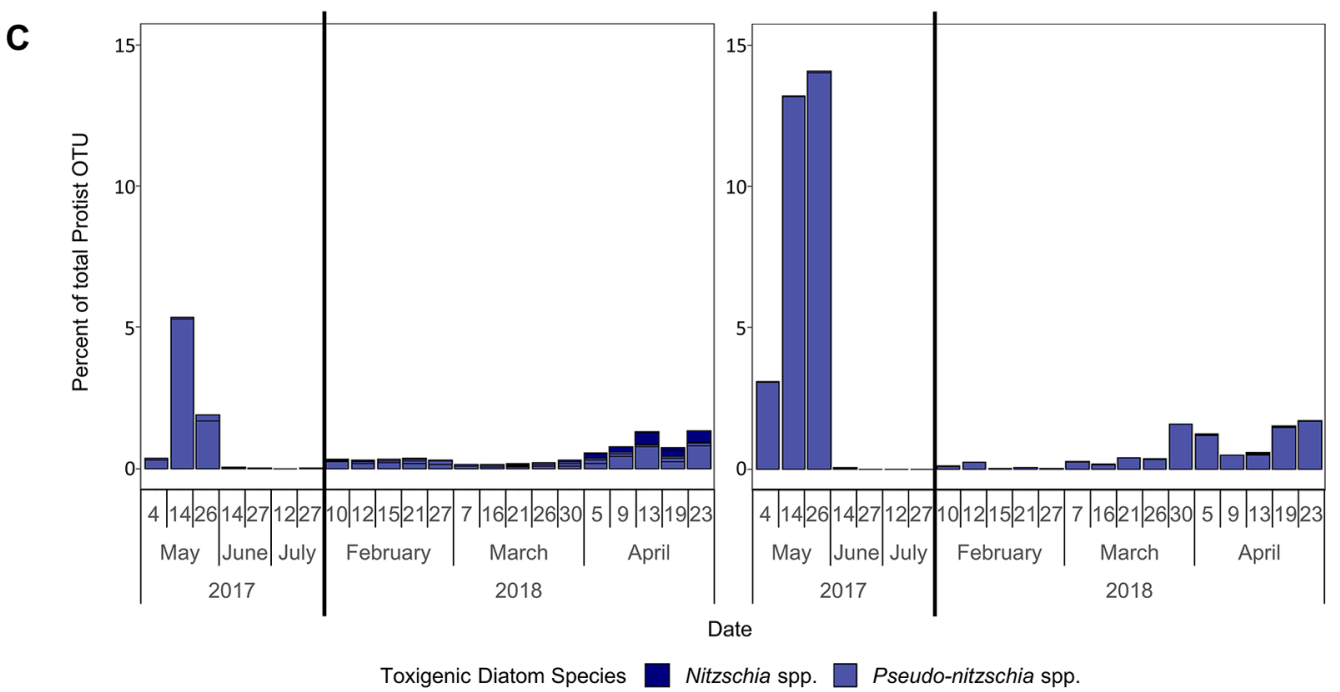

Fig. 3. Succession of toxic species in the OTU analysis. Normalized total protist OTU data (A), progression of potentially toxic dinoflagellates (B), and progression of potentially toxic diatoms (C) are shown. Solid black vertical lines indicate discontinuous measurement.

\subsection{Dissolved and particulate toxin prevalence of diatom-related domoic} acid

Various phycotoxins have been observed in Subarctic and Arctic regions, but their seasonal occurrence has not yet been assessed. So far, field surveys took place during the spring bloom event and the summer months afterwards, looking at snapshots or transects (e.g. Baggesen et al., 2012; Tillmann et al., 2014; Elferink et al., 2017; 2020a,b). This is 
A

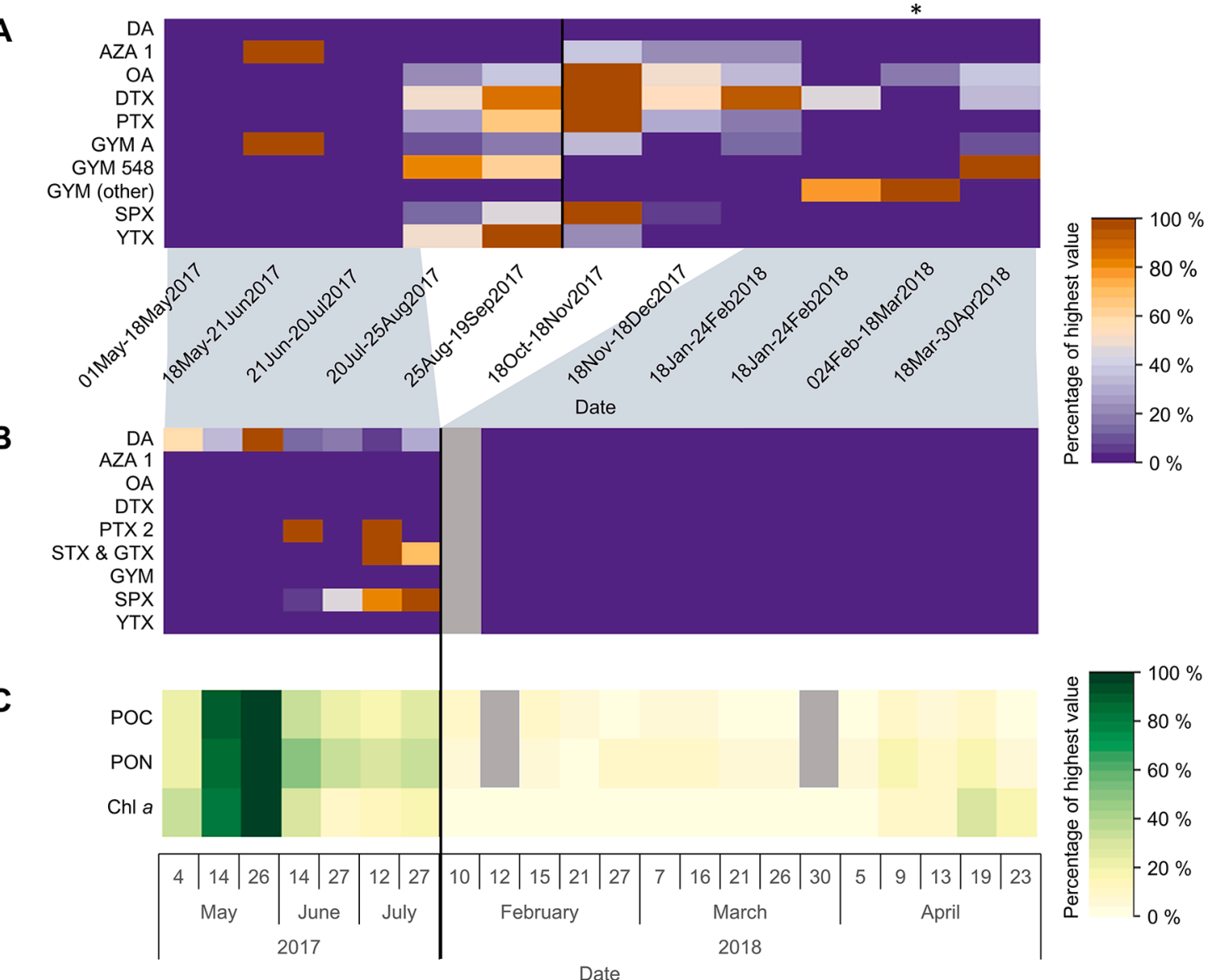

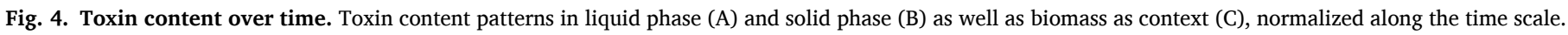

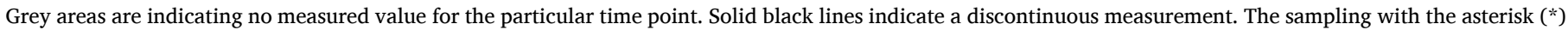

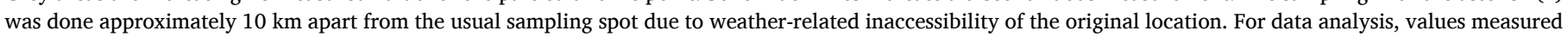
below detection limit were set as 0 . Numbers next to GYM toxins indicate $\mathrm{m} / \mathrm{z}$ of the respective measured species.

the first study to include the temporal component in context with nutrients, community structure, and biomass to allow for a developmental analysis of presence of toxins in an Arctic coastal region. The overall pattern shows a toxin succession which starts with particulate toxins occurring first and dissolved toxins later. The shift from particular into the dissolved toxin fraction (Fig. 4) may result from continuous leaking and excretion of the source organisms, but also from lysed and grazed organisms due to increased grazing pressure over time (Cembella, 2003; Ianora et al., 2011).

After spirolides (SPX), domoic acid (DA) had the highest measured content in the particulate phase, with the highest level reaching $0.05 \mathrm{pg} /$ $\mathrm{L}$ in late May. Compared to other non-Arctic regions, we observed orders of magnitude lower levels of DA (Bates et al., 2018; Torres Palenzuela et al., 2019). The increase in amount of DA in spring co-aligned with both the peak in Chl $a$ and the OTU peak of Pseudo-nitzschia spp. Previous findings of particulate DA found between July 28 and August 8 in 2012 in the Uumannaq Fjord, Vaigat Strait and Disko Bay, were also linked to Pseudo-nitzschia spp. presence in metabarcoding samples (Elferink et al., 2017). In April 2012, June 2013 and June 2014, DA-producing $P$. delicatissima was isolated from the Disko Bay area as well (Lundholm et al., 2018). In 2007, toxic $P$. seriata was found around Nuuk (Hansen et al., 2011) and in 2011 in Disko Bay (Tammilehto et al., 2012). The non-toxic $P$. arctica has also been detected before in Disko Bay (Percopo et al., 2016), suggesting that, in our case, there was probably a mixture of toxic and non-toxic species present. Several different Pseudo-nitzschia species co-occur in Arctic waters in spring, but the OTU sequences have not provided enough phylogenetic resolution allowing us to assign Pseudo-nitzschia spp. to species level.

Ecophysiological experiments have shown that DA cell quota increases during silicate and phosphate limitation, whereas nitrogen is required for the production, as DA is an amino acid derivative (Bates et al., 2018). Our field data (Fig. 2) support these findings, as silicate and phosphate were depleted at the time around the DA peak. Ammonium was still available at a relatively high concentration, not following a downwards trend like the other nutrients and possibly providing nitrogen for DA-production (Wohlrab et al., 2019). Nitrite was only present in very little densities throughout the study and nitrate was also depleted along silicate and phosphate. Previous laboratory experiments with Pseudo-nitzschia strains from the Disko Bay area showed that the presence of herbivorous copepods induced DA production (Harðardóttir et al., 2015; Lundholm et al., 2018). Copepods, which are typical diatom grazers in the Arctic, increase in biomass and grazing activity around the spring bloom in Disko Bay (Dünweber et al., 2010). The ammonium concentration in our data may additionally indicate copepod presence and their ammonium excretion and grazing activity (Corner and Newell, 1967). This implies that a combination of nutrient limitation and grazer cues may have increased particulate DA-levels. DA was the only toxin exclusively detectable in the particulate phase and not as dissolved toxin. Spatial differences could have led to the detection of DA in one location and not in the other. However, neither PSP toxins nor DA are adsorbing well to the SPATT material, resulting in a possible method bias. DA may either still be present, because it has previously been commonly found in the dissolved phase applying different detection methods (Lane et al., 2010; Pagou and Hallegraeff, 2012; Geuer et al., 
Table 2.

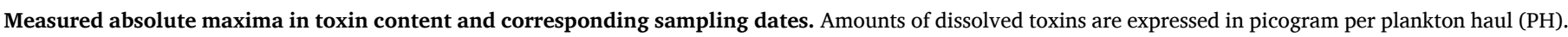
nd $=$ below detection limit. $\mathrm{nm}=$ not measured.

\begin{tabular}{|c|c|c|c|c|c|c|}
\hline & $\mathrm{pg} / \mathrm{PH}$ particulate & $\mathrm{pg} / \mathrm{sample}$ Detection limit & Sampling time point & $\mathrm{pg} /$ sample dissolved & Detection limit & Sampling time frame \\
\hline AZA1 & $\mathrm{Nd}$ & 75.00 & - & 57.00 & 8.82 & 18.05.-21.06.2017 \\
\hline DA & 81010.10 & 447.76 & 26.05 .2017 & nd & 110.08 & - \\
\hline DTX1 & nd & 1136.36 & - & 37232.29 & 750.00 & 18.01.-24.02.2018 \\
\hline DTX1 Isomer & $\mathrm{nm}$ & - & - & 24876.44 & 750.00 & 18.12.-18.01.2018 \\
\hline DTX2 & nd & 12500.00 & - & nd & 375.00 & - \\
\hline GDA & nd & 6944.44 & - & nd & 545.45 & - \\
\hline GTX 1 & nd & 0.058 & - & $\mathrm{nm}$ & - & - \\
\hline GTX 2 & nd & 0.002 & - & $\mathrm{nm}$ & - & - \\
\hline GTX 3 & 5686153.85 & 0.003 & 27.07.2017 & $\mathrm{nm}$ & - & - \\
\hline GTX 4 & nd & 0.048 & - & $\mathrm{nm}$ & - & - \\
\hline GTX 5 & nd & 0.012 & - & $\mathrm{nm}$ & - & - \\
\hline GYM A & nd & 6.25 & - & 289.00 & 0.34 & 18.05.-21.06.2017 \\
\hline GYM_494 & $\mathrm{nm}$ & - & - & 37.20 & 0.34 & 18.12.-18.01.2018 \\
\hline GYM_522 & $\mathrm{nm}$ & - & - & 48.12 & 0.34 & 18.01.-24.02.2018 \\
\hline GYM_548 & $\mathrm{nm}$ & - & - & 41.98 & 0.34 & 24.02.-18.03.2018 \\
\hline GYM_582 & $\mathrm{nm}$ & - & - & 34.10 & 0.34 & $18.01 .-24.02 .2018$ \\
\hline $\mathrm{OA}^{-}$ & nd & 2205.88 & - & 22669.10 & 1041.67 & 18.10.-18.11.2017 \\
\hline PTX2 & 25154.32 & 375.00 & 14.06 .2017 & 56293.71 & 155.84 & 18.10.-18.11.2017 \\
\hline PTX2sa & $\mathrm{nm}$ & - & - & 6993.01 & 155.84 & 18.10.-18.11.2017 \\
\hline SPX 1 & 30882.35 & 83.33 & 12.07.2017 & 3158.14 & 0.86 & 18.10.-18.11.2017 \\
\hline SPX A & 121915.82 & 83.33 & 27.07.2017 & 2386.05 & 0.86 & 18.10.-18.11.2017 \\
\hline SPX C & 113041.07 & 83.33 & 12.07.2017 & 39860.47 & 0.86 & 18.10.-18.11.2017 \\
\hline SPX G & 113041.07 & 83.33 & 12.07.2017 & 1646.51 & 0.86 & 18.10.-18.11.2017 \\
\hline 20-Me-SPX G & 283454.28 & 83.33 & 27.07.2017 & 11441.86 & 0.86 & 18.10.-18.11.2017 \\
\hline STX & 1571184.98 & 0.002 & 12.07 .2017 & $\mathrm{~nm}$ & - & - \\
\hline dc-STX & nd & 0.003 & - & $\mathrm{nm}$ & - & - \\
\hline Neo STX & nd & 0.022 & - & $\mathrm{nm}$ & - & - \\
\hline YTX & nd & 37500.00 & - & nd & 750.00 & - \\
\hline YTX Isomer & nd & 37500.00 & - & 6866.36 & 750.00 & 25.08.-18.09.2017 \\
\hline
\end{tabular}

2019). Alternatively, DA could have not been present in the water, because it presumably only leaks out of cells at high intracellular DA concentrations in the stationary growth phase of DA producers (Lundholm et al., 2004; Gai et al., 2018).

\subsection{Dissolved and particulate toxin prevalence of dinoflagellate-related toxins}

The measured variety of toxins produced by dinoflagellates was much greater and the temporal distribution therefore more complex. The most obvious peak of toxins related to dinoflagellates was observed in July for particulate toxins and in October and November for dissolved toxins. Spirolide (SPX) contents in the particulate phase clustered together with pectenotoxin (PTX) contents. This pattern of toxin clustering repeated itself time-delayed in the dissolved toxins, although these toxins also clustered together with okadaic acid (OA), one gymnodimine (GYM) and a yessotoxin isomer (YTX, Fig. 4). This suggests that the causative organisms kept the majority of toxins intracellularly and afterwards released the toxins into the water, probably due to cell death. The time gap between particulate and dissolved toxins may have been smaller than presented due to unmeasured toxin contents in the discontinuous measurements from particulate toxins and metabarcoding samples. Nevertheless, this does not affect the overall tendency of dissolved toxin patterns to repeat after the particulate toxin patterns.

The highest peaks in recorded particulate SPX in our data coincided with the metabarcoding peak of Alexandrium ostenfeldii in late July 2017. Currently, A. ostenfeldii is the only known producer of SPX (Cembella et al., 2000, 2001), but the organism is also associated to the production of paralytic shellfish toxins (PST, including saxitoxin;STX and gonyautoxins;GTX), and gymnodimines (GYM) (Salgado et al, 2015; Van de Waal et al., 2015). In August 2012, SPX-producing A. ostenfeldii strains were also documented in the Disko Bay area (Tillmann et al., 2014). The same seasonal occurrence appeared in the northern Baltic Sea with the highest $A$. ostenfeldii abundance in the warm periods of July and August (Hakanen et al., 2012), and in July 2013 in the Netherlands (Van de Waal et al., 2015). Hence, A. ostenfeldii typically appears in the warmer months after the initial spring bloom peak, both in temperate and Arctic areas. Three GYM toxins peaked in January to March in the dissolved phase. We did not observe the community structure in the time period before this measurement, so it remains speculative which organism produced the toxins. GYM was first reported to be produced by Karenia selliformis (reported as Gymnodinium sp.; Seki et al., 1996), which was not found in our metabarcoding analyses. Another source of GYM is A. ostenfeldii (reported as A. peruvianum; Van Wagoner et al., 2011, Martens et al., 2017). However, GYM was present at different time periods than SPX, so A. ostenfeldii most likely can be excluded as the GYM-producing species. This indicates that in all probability there are other, yet unidentified GYM-producing organisms in the West Greenland region. The occurrence of PTX, OA, and YTX could also not be linked to causative organisms. Possible causative organisms for these toxins that were detected in the metabarcoding data comprise Dinophysis acuminata (OA, DTX, PTX), Dinophysis spp. (OA, DTX, PTX), Gonyaulax spinifera (YTX), Prorocentrum spp. (OA) and Protoceratium reticulatum (YTX). In the relative OTU abundance of these species, no obvious temporal distribution patterns were found that coincide with the toxin patterns. For instance, in Japanese waters, Dinophysis acuminata, a potential producer of OA, DTX and PTX, appeared in the warmer months May, June and July and additionally in October, November and December (Nishitani et al., 2002). This bi-annual succession pattern cannot be observed in the metabarcoding data, but more or less in the dissolved toxin pattern, where we have a peak of OA and PTX in late summer and a peak of a DTX Isomer in winter. For some dinoflagellates like Dinophysis spp., a patchy occurrence in thin layers in the water column has been reported, which can result in sampling bias (Escalera et al., 2012). Single cells of Dinophysis were seen in inspections by microscopy of plankton net samples, which sampled the whole water column (this study). The samples used for metabarcoding were a pooled approach of different depths and not a fully integrated sample of all depths. This may have resulted in missing the distinct water column layer of occurrence for the organisms. This highlights the importance of passive sampling of dissolved toxins, which was able to detect DTX, OA and GYM in contrast to the sampling approach for particulate toxins, where none of these toxins 
were detected.

Azaspiracid-1 was detected in the dissolved phase but not in the particulate phase. Azadinium cells, producing azaspiracid-1, are below $20 \mu \mathrm{m}$ in size, and may hence have been missed in the particulate toxin phase based on $20 \mu \mathrm{m}$ plankton net hauls. Only one OTU belonging to the genus Azadinium was detected in the sequenced data, but was excluded with subsequent curation and analyses of data due to its low read numbers. A new Azadinium species named Azadinium perforatum has recently been described for West Greenlandic waters (Tillmann et al., 2020), suggesting the possibility that the DNA signature of other, AZA-producing species may have not yet been implemented in the databases that were been used for identification of our OTU data. This shows the need for the development of more and larger references databases so that less species remain invisible in a background of non-assigned reads/sequences.

\section{Conclusions}

In conclusion, the investigated area in Disko Bay, West Greenland did not exhibit an $\mathrm{HAB}$ event in the examined period, but presence of several $\mathrm{HAB}$ species and their toxins in the expected succession pattern of diatoms during the spring bloom event, followed by dinoflagellates in summer. The toxins usually appear first in the phytoplankton and are later on found dissolved in water. The observed seasonal dynamics of $\mathrm{HAB}$ species and toxins can be used as a baseline for HAB potential for this area and for comparison for future $\mathrm{HAB}$ events.

\section{Funding}

Funding provided by the Danish Research Council for Nature and Universe was given to Nina Lundholm. Financial support for Claudia Sabine Bruhn, Uwe John, and Bernd Krock was provided by the PACES II research program of the Alfred Wegener Institute, Helmholtz Centre for Polar and Marine Research. Sylke Wohlrab was funded by the Ministry for Science and Culture of Lower Saxony and the Volkswagen Foundation through the "Niedersächsisches Vorab" grant program (grant number ZN3285).

\section{Declaration of Competing Interest}

The authors declare that they have no known competing financial interests or personal relationships that could have appeared to influence the work reported in this paper.

\section{Acknowledgements}

We are grateful to Nancy Kühne for her technical assistance in the laboratory. The toxin analyses were supported by Thomas Max and Annegret Müller, whom we thank for their technical aid in the laboratory. We thank Kai-Uwe Ludwichowski for the nutrient analysis. The expeditions were conducted within the framework of the Disko Marine Basis Program, Arctic Station, Greenland and were financially and logistically supported under the PACES II Programme of the Alfred Wegener Institute, Helmholtz Centre for Polar and Marine Research, Germany. The Helmholtz Institute for Functional Marine Biodiversity is a collaboration between the Alfred Wegener Institute, Helmholtz-Centre for Polar and Marine Research, and the Carl-von-Ossietzky University Oldenburg, initially funded by the Ministry for Science and Culture of Lower Saxony and the Volkswagen Foundation through the "Niedersächsisches Vorab" grant program (grant number ZN3285).

\section{Supplementary materials}

Supplementary material associated with this article can be found, in the online version, at doi:10.1016/j.hal.2021.101978.

\section{References}

Anderson, D.M., Cembella, A.D., Hallegraeff, G.M., 2012. Progress in understanding harmful algal blooms: paradigm shifts and new technologies for research, monitoring, and management. Annu. Rev. Mar. Sci. 4, 143-176.

Arar, E.J., Collins, G.B., 1997. Method 445.0 In Vitro Determination of Chlorophyll $a$ and Pheophytin $a$ in Marine and Freshwater Algae by Fluorescence. U.S. Environmental Protection Agency, Washington, DC, pp. 1-22.

Armstrong, F.A.J., Stearns, C.R., Strickland, J.D.H, 1967. The measurement of upwelling and subsequent biological process by means of the Technicon Autoanalyzer $($ and associated equipment. Deep-Sea Res. Oceanogr. Abstr. 14, 381-389.

Baggesen, C., Moestrup, Ø., Daugbjerg, N., Krock, B., Cembella, A.D., Madsen, S., 2012. Molecular phylogeny and toxin profiles of Alexandrium tamarense (Lebour) Balech (Dinophyceae) from the west coast of Greenland. Harmful Algae 19, 108-116.

Bates, S.S., Hubbard, K.A., Lundholm, N., Montresor, M., Leaw, C.P., 2018. Pseudonitzschia, Nitzschia, and domoic acid: new research since 2011. Harmful Algae 79, $3-43$.

Brander, K.M., Milligan, S.P., Nichols, J.H., 1993. Flume tank experiments to estimate the volume filtered by high-speed plankton samplers and to assess the effect of net clogging. J. Plankton Res. 15 (4), 385-401.

Brett, D. (Ed.), 2003. Europe Review 2003/4: The Economic and Business Report (World of Information Reviews Series), 15th ed. Walden Publishing Ltd.

Cembella, A.D., Lewis, N.I., Quilliam, M.A., 2000. The marine dinoflagellateAlexandrium ostenfeldii (Dinophyceae) as the causative organism of spirolide shellfish toxins. Phycologia 39 (1), 67-74.

Cembella, A.D., 2003. Chemical ecology of eukaryotic microalgae in marine ecosystems. Phycologia 42 (4), 420-447.

Cembella, A.D., Bauder, A.G., Lewis, N.I., Quilliam, M.A., 2001. Association of the gonyaulacoid dinoflagellate Alexandrium ostenfeldii with spirolide toxins in sizefractionated plankton. J. Plankton Res. 23 (12), 1413-1419.

Corner, E.D.S., Newell, B.S, 1967. On the nutrition and metabolism of zooplankton; IV, The forms of nitrogen excreted by Calanus. J. Mar. Biolog. Assoc. UK. 47 (1), $113-120$.

Dolah, F.M.Van, 2000. Marine algal toxins: origins, health effects, and their increased occurrence. Environ. Health Perspect. 108, 133-141.

Dünweber, M., Swalethorp, R., Kjellerup, S., Nielsen, T.G., Arendt, K.E., Hjorth, M., Tönnesson, K., Møller, E.F., 2010. Succession and fate of the spring diatom bloom in Disko Bay, western Greenland. Mar. Ecol. Prog. Ser. 419, 11-29.

Eberlein, K., Kattner, G., 1987. Automatic method for the determination of orthophosphate and total dissolved phosphorus in the marine environment. Fresenius' Zeitschrift Für Analytische Chemie 326, 354-357.

Elferink, S., John, U., Neuhaus, S., Wohlrab, S., 2020a. Functional genomics differentiate inherent and environmentally influenced traits in dinoflagellate and diatom communities. Microorganisms 8 (567), 1-22.

Elferink, S., Neuhaus, S., Wohlrab, S., Toebe, K., Voß, D., Gottschling, M., Lundholm, N., Krock, B., Koch, B.P., Zielinski, O., Cembella, A., John, U., 2017. Molecular diversity patterns among various phytoplankton size-fractions in West Greenland in late summer. Deep-Sea Res. Pt. I 121, 54-69.

Elferink, S., Wohlrab, S., Neuhaus, S., Cembella, A., Harms, L., John, U., 2020. Comparative metabarcoding and metatranscriptomic analysis of microeukaryotes within coastal surface waters of West Greenland and Northwest Iceland. Front. Mar. Sci. 7 (439), 1-20.

Escalera, L., Pazos, Y., Dolores, M., Reguera, B., 2012. A comparison of integrated and discrete depth sampling for monitoring toxic species of Dinophysis. Mar. Pollut. Bull. 64, 106-113.

Falkowski, P.G., 1994. The role of phytoplankton photosynthesis in global biogeochemical cycles. Photosynth. Res. 39, 235-258.

Field, C.B., Behrenfeld, M.J., Randerson, J.T., 1998. Primary production of the biosphere: integrating terrestrial and oceanic components. Science 281, 237-241.

Flynn, K.J., Mitra, A., Anestis, K., Anschütz, A.A., Calbet, A., Duarte Ferreira, G., Gypens, N., Hansen, P.J., John, U., Lapeyra Martin, J., Mansour, Maselli, M., Medić, N., Norlin, A., Not, F., Pitta, P., Romano, F., Saiz, E., Schneider, L.K., Stolte, W., Traboni, C., 2019. Mixotrophic protists and a new paradigm for marine ecology: where does plankton research go now? J. Plankton Res. 41 (4), 375-391.

Fragoso, G.M., Poulton, A.J., Yashayaev, I.M., Head, E.J.H., Purdie, D.A, 2017. Spring phytoplankton communities of the Labrador Sea (2005 - 2014): pigment signatures, photophysiology and elemental ratios. Biogeosciences 14, 1235-1259.

Gai, F.F., Hedemand, C.K., Louw, D.C., Grobler, K., Krock, B., Moestrup, Ø. Lundholm, N., 2018. Morphological, molecular and toxigenic characteristics of Namibian Pseudo-nitzschia species - including Pseudo-nitzschia bucculenta sp. nov. Harmful Algae 76, 80-95.

Gao, C., Lin, S., Chen, M., Hong, J., Liu, C., 2019. Toxicon Prevalence of phycotoxin contamination in shellfish from the Northern Bering Sea and the Chukchi Sea. Toxicon 167, 76-81.

Geuer, J.K., Krock, B., Leefmann, T., Koch, B.P., 2019. Quantification, extractability and stability of dissolved domoic acid within marine dissolved organic matter. Mar. Chem. 215, 103669.

Glibert, P.M., 2016. Margalef revisited: A new phytoplankton mandala incorporating twelve dimensions, including nutritional physiology. Harmful Algae 55, 25-30.

Grasshoff, K., Ehrhardt, M., Kremling, K., 1983. Methods of Seawater Analysis, 2nd ed. John Wiley \& Sons, Weinheim, Germany.

Guillou, L., Bachar, D., Audic, S., Bass, D., Berney, C., Bittner, L., Boutte, C., Burgaud, G., de Vargas, C., Decelle, J., del Campo, J., Dolan, J.R., Dunthorn, M., Edvardsen, B., Holzmann, M., Kooistra, W.H.C.F., Enrique, L., Le Bescot, N., Logares, R., Mahé, F., Massana, R., Montresor, M., Morard, R., Not, F., Pawlowski, J., Probert, I., Sauvadet, A.-L., Siano, R., Stoeck, T., Vaulot, D., Zimmermann, P., Christen, R, 2013. 
The Protist Ribosomal Reference database $\left(\mathrm{PR}^{2}\right)$ : a catalog of unicellular eukaryote Small Sub-Unit rRNA sequences with curated taxonomy. Nucleic Acids Res. Spec. Publ. 41, 597-604.

Guo, L., Sui, Z., Liu, Y., 2016. Quantitative analysis of dinoflagellates and diatoms community via Miseq sequencing of actin gene and v9 region of 18S rDNA. Sci. Rep. 1-9 (October).

'HAEDAT Event NO-17-038', 2017 <http://haedat.iode.org/viewEvent.php? eventID $=5915>$ [accessed 29 April 2020].

Hakanen, P., Suikkanen, S., Franzén, J., Franzén, H., Kankaanpää, H., Kremp, A., 2012. Bloom and toxin dynamics of Alexandrium ostenfeldii in a shallow embayment at the SW coast of Finland, northern Baltic Sea. Harmful Algae 15, 91-99.

Hallegraeff, G.M., 2010. Ocean climate change, phytoplankton community responses, and harmful algal blooms: a formidable predictive challenge. J. Phycol. 46, 220-235.

Hallegraeff, G.M., Anderson, D.M., Cembella, A.D., 2003. Manual on Harmful Marine Microalgae. UNESCO Publishing.

Hansen, L.R., Soylu, S.í, Kotaki, Y., Moestrup, Ø., Lundholm, N., 2011. Toxin production and temperature-induced morphological variation of the diatom Pseudo-nitzschia seriata from the Arctic. Harmful Algae 10 (6), 689-696.

Harðardóttir, S., Pančić, M., Tammilehto, A., Krock, B., Møller, E.F., Nielsen, T.G. Lundholm, N., 2015. Dangerous relations in the arctic marine food web: interaction between toxin producing Pseudo-nitzschia diatoms and Calanus copepodites. Mar. Drugs 13 (June), 3809-3835.

Hasle, G.R., 2002. Are most of the domoic acid-producing species of the diatom genus Pseudo-nitzschia cosmopolites? Harmful Algae 1, 137-146.

Hegseth, E.N., Tverberg, V., 2013. Effect of Atlantic water in flow on timing of the phytoplankton spring bloom in a high Arctic fjord (Kongsfjorden, Svalbard). J. Marine Syst. 113-114, 94-105.

Hinder, S.L., Hays, G.C., Edwards, M., Roberts, E.C., Walne, A.W., Gravenor, M.B., 2012 Changes in marine dinoflagellate and diatom abundance under climate change. Nat. Clim. Change 2, 271-275.

Hobson, K.A., Welch, H.E., 1992. Determination of trophic relationships within a high Arctic marine food web using $813 \mathrm{C}$ and $815 \mathrm{~N}$ analysis. Mar. Ecol. Prog. Ser. 84, 9-18.

Ianora, A., Bentley, M.G., Caldwell, G.S., Casotti, R., Cembella, A.D., Engström-Öst, J., Halsband, C., Sonnenschein, E., Legrand, C., Llewellyn, C.A., Paldavičienë, A., Pilkaityte, R., Pohnert, G., Razinkovas, A., Romano, G., Tillmann, U., Vaiciute, D. 2011. The relevance of marine chemical ecology to plankton and ecosystem function: an emerging field. Mar. Drugs 9, 1625-1648.

John, U., Litaker, R.W., Montresor, M., Murray, S., Brosnahan, M.L., Anderson, D.M., 2014. Formal revision of the Alexandrium tamarense species complex (Dinophyceae) taxonomy: the introduction of five species with emphasis on molecular-based (rDNA) classification. Protist 165 (6), 779-804.

Koroleff, F., 1969. Direct Determination of Ammonia in Natural Waters as Indophenol Blue. International Council for the Exploration of the Sea.

Krock, B., Schloss, I.R., Trefault, N., Tillmann, U., Hernando, M., Deregibus, D., Antoni, J., Almandoz, G.O., Hoppenrath, M., 2020. Detection of the phycotoxin pectenotoxin-2 in waters around King George Island. Antarctica. Polar Biol. 43, 263-277.

Krock, Bernd, Tillmann, Urban, John, Uwe, Cembella, Allan, 2008. LC-MS-MS aboard ship: tandem mass spectrometry in the search for phycotoxins and novel toxigenic plankton from the North Sea. Anal. Bioanal. Chem. 392, 797-803.

Lane, J.Q., Roddam, C.M., Langlois, G.W., Kudela, R.M., 2010. Application of solid phase adsorption toxin tracking (SPATT) for field detection of the hydrophilic phycotoxins domoic acid and saxitoxin in coastal California. Limnol. Oceanogr. 8, 645-660.

Lefebvre, K.A., Quakenbush, L., Frame, E., Burek Huntington, K., Sheffield, G., Stimmelmayr, R., Bryan, A., Kendrick, P., Ziel, H., Goldstein, T., Snyder, J.A., Gelatt, T., Gulland, F., Dickerson, B., Gill, V., 2016. Prevalence of algal toxins in Alaskan marine mammals foraging in a changing arctic and subarctic environment. Harmful Algae 55, 13-24.

Lundholm, N., Hansen, P.J., Kotaki, Y., 2004. Effect of pH on growth and domoic acid production by potentially toxic diatoms of the genera Pseudo-nitzschia and Nitzschia. Mar. Ecol. Prog. Ser. 273, 1-15.

Lundholm, N., Krock, B., John, U., Skov, J., Cheng, J., Pančić, M., Wohlrab, S., Rigby, K., Gissel Nielsen, T., Selander, E., Harðardóttir, S., 2018. The distribution and impacts of harmful algal bloom species in eastern boundary upwelling systems. Harmful Algae 85, 33-52.

MacKenzie, L., Beuzenberg, V., Holland, P., McNabb, P., Selwood, A., 2004. Solid phase adsorption toxin tracking (SPATT): a new monitoring tool that simulates the biotoxin contamination of filter feeding bivalves. Toxicon 44, 901-918.

Marquardt, M., Vader, A., Stübner, E.I., Reigstad, M., Gabrielsen, T.M., 2016. Strong Seasonality of Marine Microbial Eukaryotes in a High-Arctic Fjord (Isfjorden, in West Spitsbergen, Norway). Appl. Environ. Microbiol. 82 (6), 1868-1880.

Martens, H., Tillmann, U., Harju, K., Dell'Aversano, C., Tartaglione, L., Krock, B., 2017. Toxin Variability Estimations of 68 Alexandrium ostenfeldii (Dinophyceae) Strains from The Netherlands Reveal a. Novel Abundant Gymnodimine. Microorganisms 5 (29), 1-24.

Mauritsen, T., 2016. Greenhouse warming unleashed. Nat. Geosci. 9 (4), 268-269.

McBean, G., Alekseev, G., Chen, D., Førland, E., Fyfe, J., Groisman, P.Y., King, R., Melling, H., Vose, R., Whitfield, P.H., 2005. Arctic Climate: Past and Present. Arctic Climate Impacts Assessment (ACIA), pp. 21-60.

McCarthy, G.D., Haigh, I.D., 2015. Ocean impact on decadal Atlantic climate variability revealed by sea-level observations. Nature $521,508-510$.

Meire, L., Mortensen, J., Meire, P., Sejr, M.K., Rysgaard, S., Nygaard, R., Huybrechts, P., Meysman, F.J.R, 2017. Marine-terminating glaciers sustain high productivity in Greenland fjords. Glob. Change Biol. 23 (12), 1-14.
Moestrup, Ø., Akselmann-Cardella, R., Churro, C., Fraga, S., Hoppenrath, M., Iwataki, M., Larsen, J., Lundholm, N., Zingone, A. (2009). IOC-UNESCO taxonomic reference list of harmful micro algae.

Moritz, R.E., Bitz, C.M., Steig, E.J., 2002. Dynamics of recent climate change in the arctic. Science 297, 1497-1503.

Munday, R., Quilliam, M.A., LeBlanc, P., Lewis, N., Gallant, P., Sperker, S.A., Ewart, H.S., MacKinnon, S.L., 2012. Investigations into the toxicology of spirolides, a group of marine phycotoxins. Toxins 4 (1), 1-14.

Nishitani, G., Sugioka, H., Imai, I., 2002. Seasonal distribution of species of the toxic dinoflagellate genus Dinophysis in Maizuru Bay (Japan), with comments on their autofluorescence and attachment of picophytoplankton. Harmful Algae 1, 253-264.

Okolodkov, Y.B., Dodge, J.D., 1996. Biodiversity and biogeography of planktonic dinoflagellates in the Arctic Ocean. J. Exp. Mar. Biol. Ecol. 202 (1), 19-27.

Overpeck, J., Hughen, K., Hardy, D., Bradley, R., Case, R., Douglas, M., Finney, B., Gajewski, K., Jacoby, G., Jennings, A., Lamoureux, S., Lasca, A., Macdonald, G., Moore, J., Retelle, M., Smith, S., Wolfe, A., Zielinski, G., 1997. Arctic environmental change of the last four centuries. Science 278, 1251-1257.

Core Writing Team, IPCC, 2007. Climate change 2007: Synthesis Report. In: Pachauri, R. K., Reisinger, A. (Eds.). IPCC, Geneva, Switzerland, p. 104. Contribution of Working Groups I, II and III to the Fourth Assessment Report of the Intergovernmental Panel on Climate Change.

Core Writing Team, IPCC, 2014. Climate Change 2014: Synthesis Report. In: Pachauri, R. K., Meyer, L.A. (Eds.). IPCC, Geneva, Switzerland, p. 151. Contribution of Working Groups I, II to the Fifth Assessment Report of the Intergovernmental Panel on Climate Change.

Pagou, K.A., Hallegraeff, G.M. (Eds.), 2012. Proceedings of the 14th International Conference on Harmful Algae. International Society for the Study of Harmful Algae and Intergovernmental Oceanographic Commission of UNESCO, 2012.

Peperzak, L., 2003. Climate change and harmful algal blooms in the North Sea. ACTA Oecol. 24, S139-S144.

Percopo, I., Ruggiero, M.V., Balzano, S., Gourvil, P., Lundholm, N., Tammilehto, A., Vaulot, D., 2016. Pseudo-nitzschia arctica sp. nov., a new cold-water cryptic Pseudonitzschia species within theP. pseudodelicatissima complex. J. Phycol. 52, 184-199.

Piredda, R., Tomasino, M. P., Erchia, A. M. D. (2016). Diversity and temporal patterns of planktonic protist assemblages at a Mediterranean LTER site.

Pitcher, Grant C., Weeks, Scarla J., 2006. The Variability and Potential for Prediction of Harmful Algal Blooms in the Southern Benguela Ecosystem. Large Mar. Ecosyst. 14, 125-146.

Ralston, D.K., Keafer, B.A., Brosnahan, M.L., Anderson, D.M., 2014. Temperature dependence of an estuarine harmful algal bloom: resolving interannual variability in bloom dynamics using a degree-day approach. Limnol. Oceanogr. 59 (4), $1112-1126$.

Raymont, J.E.G, 1980. Plankton and Productivity in the Oceans (2nd ed., Vol. 2). Pergamon Press Ltd., Oxford, England.

Reguera, B., Riobó, P., Rodríguez, F., Díaz, P.A., Pizarro, G., Paz, B., Franco, J.M., Blanco, J., 2014. Dinophysis toxins: causative organisms, distribution and fate in shellfish. Mar. Drugs 394-461.

Richard, D., Arsenault, E., Cembella, A.D., Quilliam, M.A., 2000. Investigations into the toxicology and pharmacology of spirolides, a novel group of shellfish toxins. In: Hallegraeff, G.M., Blackburn, S.I., Bolch, C.J., Lewis, R.J. (Eds.), Harmful Algal Blooms 2000. International Oceanographic Commission (UNESCO), Paris.

Salgado, P., Riobó, P., Rodríguez, F., Franco, J.M., Bravo, I., 2015. Differences in the toxin profiles of Alexandrium ostenfeldii (Dinophyceae) strains isolated from different geographic origins: evidence of paralytic toxin, spirolide, and gymnodimine. Toxicon 103, 85-98.

Seki, T., Satake, M., MacKenzie, A.L., Kaspar, H.F., Yasumoto, T, 1996. Gymnodimine, a novel toxic imine isolated from the Foveaux Strait oysters and Gymnodinium sp. In: Yasumoto, T., Oshima, Y., Fukuyo, Y. (Eds.), Harmful and Toxic Algal Blooms. Intergovernmental Oceanographic Commission of UNESCO, pp. 495-498.

Seuthe, L., Töpper, B., Reigstad, M., Thyrhaug, R., Vaquer-Sunyer, R., 2011. Microbial communities and processes in ice-covered Arctic waters oft he northwestern Fram Strait $\left(75\right.$ to $80^{\circ} \mathrm{N}$ ) during the vernal pre-bloom phase. Aquat. Microb. Ecol. 64, 253-266.

Smayda, T.J., 1997. Harmful algal blooms: Their ecophysiology and general relevance to phytoplankton blooms in the sea. Limnol. Oceanogr. 42 (5), 1137-1153.

Smayda, T.J., Trainer, V.L., 2010. Dinoflagellate blooms in upwelling systems: Seeding, variability, and contrasts with diatom bloom behaviour. Prog. Oceanogr. 85, 92-107.

Tammilehto, A., Gissel, T., Krock, B., Friis, E., Lundholm, N., 2012. Calanus spp. - vectors for the biotoxin, domoic acid, in the Arctic marine ecosystem? Harmful Algae 20, $165-174$.

Sprong, P.A.A., Fofonova, V., Wiltshire, K.H., Neuhaus, S., Ludwichowski, K.U., Käse, L., Androsov, A., Metfies, K, 2020. Spatial dynamics of eukaryotic microbial communities in the German Bight. J. Sea Res. 163, 101914.

Tammilehto, A., Watts, P.C., Lundholm, N., 2017. Isolation by time during an arctic phytoplankton spring bloom. J. Eukaryot. Microbiol. 64, 248-256.

Tillmann, U., Edvardsen, B., Krock, B., Smith, K.F., Paterson, R.F., Voß, D., 2018. Diversity, distribution, and azaspiracids of Amphidomataceae (Dinophyceae) along the Norwegian coast. Harmful Algae 80, 15-34.

Tillmann, U., Gottschling, M., Nézan, E., Krock, B., 2015. First records of Amphidoma languida and Azadinium dexteroporum (Amphidomataceae, Dinophyceae) from the Irminger Sea off Iceland. Mar. Biodivers. Rec. 8, 1-11.

Tillmann, U., Kremp, A., Tahvanainen, P., Krock, B., 2014. Characterization of spirolide producing Alexandrium ostenfeldii (Dinophyceae) from the western Arctic. Harmful Algae 39, 259-270. 
Tillmann, U., Wietkamp, S., Krock, B., Tillmann, A., Voss, D., Gu, H., 2020. Amphidomataceae (Dinophyceae) in the western Greenland area, including description of Azadinium perforatum sp. nov. Phycologia 59 (1), 63-88.

Torres Palenzuela, J.M., Gonzáles Vilas, L., Bellas, F.M., Garet, E., GonzálezFernández, Á., Spyrakos, E, 2019. Pseudo-nitzschia blooms in a coastal upwelling system: remote sensing detection. Toxicity and Environmental Variables. Water 11 $1-24$.

Vahl, B., Kleemann, N. (Eds.), 2019. Greenland in Figures. Statistics Greenland.

Van de Waal, D.B., Tillmann, U., Martens, H., Krock, B., van Scheppingen, Y., John, U. 2015. Characterization of multiple isolates from an Alexandrium ostenfeldii bloom in The Netherlands. Harmful Algae 49, 94-104.

Wadham, J.L., Hawkings, J., Telling, J., Chandler, D., Alcock, J., Lawson, E., 2016. Sources, cycling and export of nitrogen on the Greenland Ice Sheet. Biogeosciences Discuss 13, 1-30.
Van Wagoner, R.M., Misner, I., Tomas, C., Wright, J.L.C, 2011. Occurrence of 12-methylgymnodimine in a spirolide-producing dinoflagellate Alexandrium peruvianum and the biogenetic implications. Tetrahedron Lett. 52 (33), 4243-4246.

Wells, M.L., Trainer, V.L., Smayda, T.J., Karlson, B.S.O., Trick, C.G., Kudela, R.M., Ishikawa, A., Bernard, S., Wulff, A., Anderson, D.M., Cochlan, W.P., 2015. Harmful algal blooms and climate change: learning from the past and present to forecast the future. Harmful Algae 49, 68-93.

Wohlrab, S., John, U., Klemm, K., Eberlein, T., Forsberg Grivohiannis, A.M., Krock, B., Frickenhaus, S., Bach, L., Rost, B., Riebesell, U., Van de Waal, D.B., 2019. Ocean acidification increases domoic acid contents during a spring to summer succession of coastal phytoplankton. Harmful Algae 92, 101697.

Zingone, A., Oksfeldt Enevoldsen, H., 2000. The diversity of harmful algal blooms: a challenge for science and management. Ocean. Coast. Manag. 43, 725-748. 